\title{
Students' Combinatorial Thinking Processes in Solving Mathematics Problem
}

\author{
Gusti Uripno $^{1}$, Abdul Haris Rosyidi ${ }^{2}$ \\ ${ }^{1}$ Universitas Negeri Surabaya, gustiuripno16030174003@mhs.unesa.ac.id \\ 2Universitas Negeri Surabaya, abdulharis@unesa.ac.id
}

\begin{abstract}
ABSTRAK
Berpikir kombinatorik merupakan cara berpikir dalam menyelesaikan permasalahan kombinatorik. Permasalahan kombinatorik merupakan salah satu permasalahan yang sulit untuk diselesaikan siswa. Penelitian ini bertujuan untuk menganalisis proses berpikir kombinatorik siswa dalam menyelesaikan masalah. Diberikan dua permasalahan kombinatork, yaitu masalah yang memuat aturan perkalian dan kombinasi. Permasalahan diberikan kepada dua siswa SMA kelas XI. Hasil yang diperoleh adalah ada kecenderungan untuk subjek laki-laki melakukan pengerjaan dengan dua cara yang berbeda yaitu menghitung langsung dan dengan bantuan bagan. Sementara subjek perempuan melakukan pengerjaan dengan satu cara yakni dengan menghitungnya secara langsung. Pada permasalahan lebih kompleks yakni tentang kombinasi, model berpikir siswa melalui tahapan set of outcomes. Dari penelitian ini diharapkan pembelajaran materi kombinatorik ditekankan pada penemuan rumus oleh siswa sendiri secara induktif, terlebih secara deduktif. Sehingga dalam hal ini siswa lebih memaknai rumus kombinatorik.
\end{abstract}

Kata Kunci: Kombinatorik, Combinatorial Thinking, permasalahan kombinatorik.

\begin{abstract}
Combinatorial thinking is a way of thinking in solving combinatory problems. Combinatory problems are one of the difficult problems for students to solve. This study aims to analyses students' combinatorial thinking processes in solving problems. Given two combinatory problems that consist of problems with multiplication rule and combination. The Problems were given to two $11^{\text {th }}$ grade senior-high school students. The results obtained were that there was a tendency for male Participants to do the two different ways which are direct counting and using diagram. The female participants did the work with one way which is direct counting. On more complex issues, namely about combination, students' thinking models go through stages of set of outcomes. From this research, it is expected that combinatory material learning is emphasized on the discovery of formulas by students themselves inductively, especially deductively. So that in this case the students interpret the combinatory formula more.
\end{abstract}

Keyword: Combinatory, Combinatorial thinking, combinatory problems.

\section{Introduction}

Combinatorial Thinking is interesting content to study. Lockwood and Reed [1] have looked at how one generates a combinatoric problem reviewed by a combinatorial 
thinking model in [2]. Lockwood and Reed [3] examined how to improve combinatoric activity through practice. Combinatorial thinking is a type of thinking that is done in finding solutions to discrete problems [4]. Combinatorial thinking is a person's thinking ability in solving combinatoric problems and their techniques and strategies [5]. Combinatorial thinking includes how one tries to calculate the possibilities in a combination of several objects from the available objects. To analyze how the Combinatorial Thinking process takes place, problems that are associated with combinatorics are used. Because combinatorial thinking has a process, it will analyze the stages of each step to solve the problem.

Combinatorics is one method in enumeration. In discrete mathematics, combinatorics hold the main key in solving many enumeration problems. Budayasa [6] states that the enumeration section itself includes multiplication rules, addition rules, permutations and combinations. This section is a basic combinatoric part. Basic combinatorics themselves are part of discrete mathematics that is at the beginning of the section. Being the most basic part, the basic combinatorics need to be mastered first from the beginning before going into other parts of discrete mathematics. In further cases, the application of this combinatoric includes other branches of mathematics. This indication is indicated by adding a new section to one of the number theory books. The addition of this section will be very helpful in proving theorems so that they are more efficient [7]. Combinatorics has a broader scope in all aspects of life which includes computation, probability, and enumeration [8]. Some of these applications certainly show how important combinatorial thinking in daily life.

Combinatoric topics is also one of the students' difficulties on mathematics Participants because it is hard to be understood. Even in Melusova and Vindermanova [9] combinatorics are not only hard for students, but teachers also. teacher also experience difficulties in teaching this material. It becomes a challenge for all educators, especially mathematics, to study more about combinatorics and problems faced by students. Students also find it difficult to propose combinatoric-related problems, so that to analyze problems is also difficult [10]. Most students when encountering enumeration problems will experience difficulties. Not only students but college graduate students also experience the same difficulties [2].

Research conducted by Melusova and Vindermanova [9] classifies strategies in resolving combinatoric problems that students make. The results of the study were in the form of comparison of efficiency of each strategy carried out by students. In another study, Lockwood [10] calcifies the model of combinatorial thinking. From these studies, it shows that combinatorial thinking itself needs to be studied more deeply for educational needs.

In combinatoric thinking [2] divides this thinking model into 3 parts, namely set of outcomes, counting process, and formula / expression. These three parts of the model have relevance as explained in Figure 1. In the picture set of outcomes has a relationship with the counting process. Likewise the counting process has a relationship with the formula / expression. However, formula / expression and set of outcomes have a low relationship. Set of outcomes is the most fundamental way to solve combinatoric problems [2].

This research aims to analyze students' combinatorical thinking process based on Lockwood's combinatorical thinking model [2]. This study looks at how students solve each combinatoric problem at each stage. In previous studies many things have been examined about combinatorial thinking. but it has not been searched for how the steps students take and how students use that step. 


\section{Method}

This research aims to analyze students' combinatorical thinking process based on Lockwood's combinatorical thinking model [2]. This study looks at how students solve each combinatoric problem at each stage. In previous studies many things have been examined about combinatorial thinking. but it has not been searched for how the steps students take and how students use that step.

This research is a qualitative descriptive study. Participants are selected from class XI students and have not received combinatoric material in their teaching and learning activities. This research uses two Participants, namely male and female. Male Participants came from urban schools and female Participants came from rural schools. In this study the Participant was given a test and then interviewed based on the results of the process. From these two stages, the answers to the Participants will be analyzed based on the results of the tests and interviews with the help of Lockwood's Combinatorial Thinking Model [2]. Lockwood [2] divide the model become three parts which are Set of outcomes, counting process, Set of outcomes, and formula/expression. Each part has correlation to each other.

Set of outcomes is to make a set of possibilities. Examples of students entering the stage of set of outcomes are students making tables, or diagrams to determine all possibilities that arise. Counting process is the process of counting or solving problems by enumerating both mentally or physically. Counting process also covers how from student problems raises numbers so that they are more meaningful in context. An example is that students are able to express the value of the application of the multiplication rules that have been formulated, calculating the list of possibilities that exist. So from these two definitions, the two parts have a close relationship because after counting someone will try to find other possibilities and recalculate. Formula is using mathematical operators such as multiplication, addition, combination, permutation etc. One example is students declaring a solution in the form $\left(\begin{array}{l}7 \\ 5\end{array}\right)$ or in the operation $3 \times 2+8$. The reason why the relationship between set of outcomes and formulas is very weak, this is due to both of them are opposite ways of thinking. Formulas formally use formulas and set of outcomes in an informal way, namely by manual methods without mathematical operators [2].

Depends on the description, we code every relation between components of the model. So we have this following table.

TABLE 1 Relations codes

\begin{tabular}{|l|l|}
\hline \multicolumn{1}{|c|}{ Stages } & Codes \\
\hline Counting process $\rightarrow$ Formula/Expression & CF1 \\
\hline Formula/Expression $\rightarrow$ Counting process & CF2 \\
\hline Counting process $\rightarrow$ Set of outcomes & CS1 \\
\hline Set of outcomes $\rightarrow$ Counting process & CS2 \\
\hline Set of outcomes $\rightarrow$ Formula/Expression & SF1 \\
\hline Formula/Expression $\rightarrow$ Set of outcomes & SF2 \\
\hline
\end{tabular}




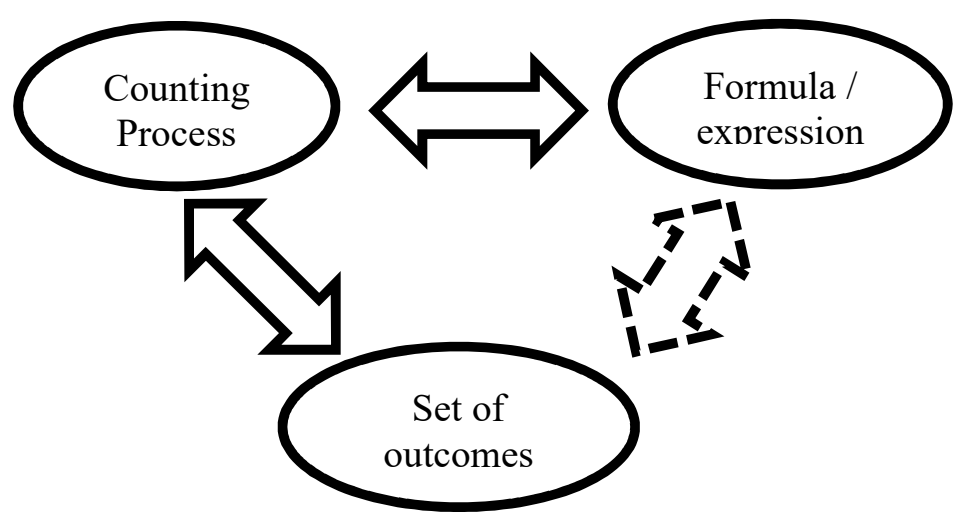

Figure 1 Lockwood's Combinatorial Thinking Model [2]

The combinatoric problems developed by Melusova and Vindermanova [9] which are given to the Participant are:

Problem 1:

1. Three friends namely Nana, Seli, and Ita. Each uploads a photo on Facebook and each of them likes each other including himself.

a.) How many likes have been recorded recorded by Facebook?

b.) How many likes does Facebook record if there are 10 girls?

c.) Try to describe how to solve it for any number of girls!

Problem 2 :

2. Fabrics with 4 colors namely red, yellow, green and blue. If from the four colors will be made with a composition of 2 colors.

a.) How many flags are arranged by different color compositions?

b.) How many flags are arranged in different colors if there are 12 colors available?

c.) Try to describe how to solve it for any desired number of colors!

Problem 1 is the application of multiplication rules. The second problem is about the application of combinations. Problem number 2 is certainly more complex than problem number 1 . There are 3 points for each problem, namely (a), (b), and (c). Points (a) are used to determine the strategy used. In point (b) it is tested about consistency and students' understanding of the first steps they take. In point (c) it is shown how students make their announcements. So with point (c), the researcher can confirm whether in the problem one has found the formula or not.

\section{Result}

\subsection{Problems 1}

The results of Participant 1 are shown in Figure 2.

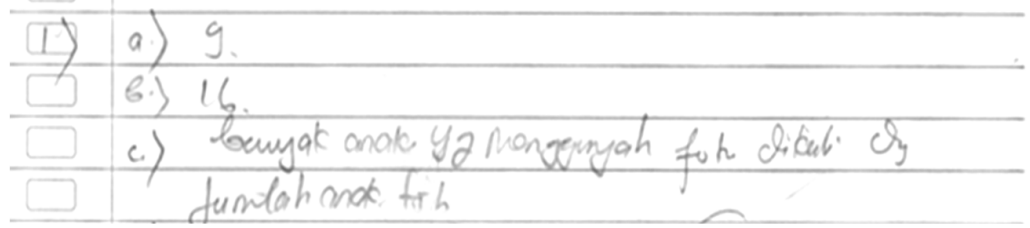

Figure 2. Results of work on Participant 1 on problem 1 
From these results, interviews were then conducted to clarify the intent of the Participant's writing. Below are the results of the interview with $\mathrm{P}$ is interviewer and $\mathrm{S}$ is participant.

P: First number one, how do you finish it?

$\boldsymbol{S}$ : there are three children uploading photos, then there are also 3 likes so there are 3 times 3 to 9. (CF1)

P: you go straight?

S: yes

...

$\boldsymbol{P}$ : then which point (b)?

S: I multiply directly, if there are 4 children so that directly 4 times 4 is equal to 16. (CF2)

$P$ : directly use multiplication?

S: yes

$P$ : what is point (c)?

$S$ : by multiplying the number of children plus the number of children.

$P$ : what do you mean?

$\boldsymbol{S}$ : there are 4 children uploading photos of each uploading a photo of one child like the picture itself, it will be 4 and then the child is 4 and then multiplied. (CF1)

From the results of students written response and interviews conducted on Participant 1, Participant 1 performs calculations using the multiplication rule. On the first point the Participant gets likes recorded by Facebook is 9. Participant 1 multiplies 3 by 3 so that the value is obtained. so also in point (b). Participant 1 can also formulate these problems informally. In general, the processing of Participant 1 is presented in Figure 3 below.

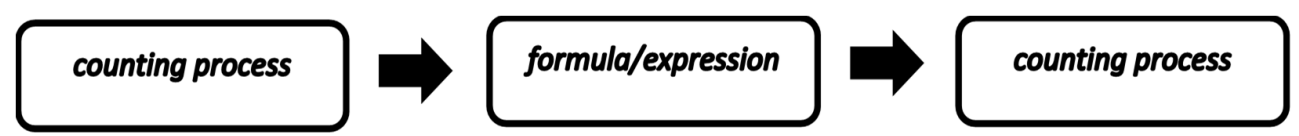

Figure 3. Combinatorial thinking process Participant 1 on problem 1

In problem 1, Participant 1 goes through stages in Lockwood's combinatorial thinking model [2]. The process carried out by the Participant can be seen from the excerpt of the interview when the Participant tries to explain the work of point 3 . This is because for each point of work done in the same way. So that researchers believe by knowing how the explanation of the Participant at the last point can represent each point. At first the Participant started with a counting process. The Participant represents number 3 which is then multiplied by 3 is the number of children who like each other and will be recorded by Facebook. From context number 1, it can be ascertained that the first student tried to bring the context of the problem and made a number by marking each child as 1 number. Then the Participant explained that the interpretation of many children was multiplied by the number of children. In this section the Participant composes the problem by raising a mathematical expression in the form of multiplication. In this section the Participant enters formula / expression. In the formula / expression section, Participant 1 composes it because each child likes himself and 2 other friends. Meanwhile, the number of children is 3 people, so if everyone likes 3 times, the number of likes recorded by Facebook is $3 \times 3$ likes. From the multiplication form Participant 1 completes by multiplying and obtaining results. This means that Participant 1 starts the counting process with result 9 based on the formula / expression that appears as the previous stage. 
Participant 1, which has stated the solution in the form of a multiplication formula, restates the form of multiplication into an ordinary number. So here the counting process carried out by Participant 1 is to calculate the result of $3 \times 3$ so that the result is 9 .

Meanwhile, Participant 2 does the same work with Participant 1 but there are stages 2 times done by the Participant 2. The results of the work of Participant 2 are shown in Figure 4.

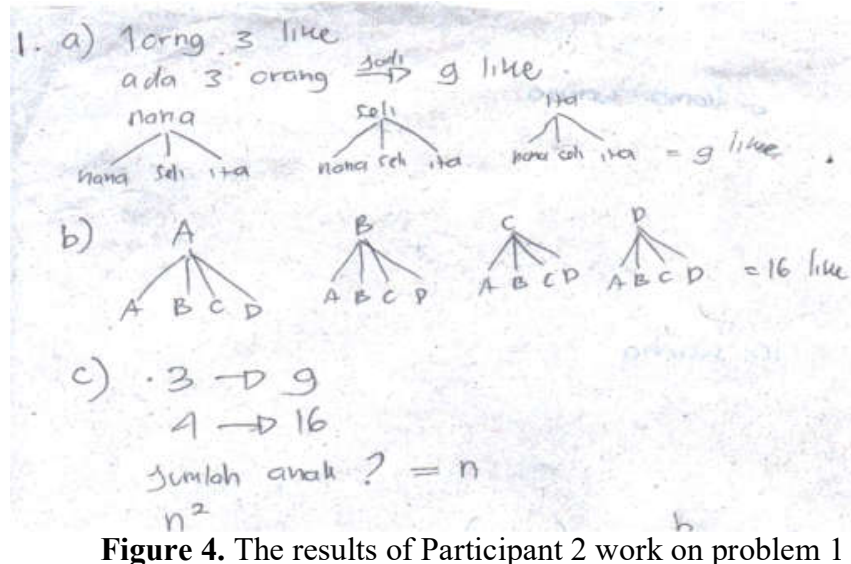

From the results of the work on Participant 2 then a further interview is carried out. The following are excerpts of the interview.

$\boldsymbol{P}$ : This is from your answer yesterday. First it's about three friends who like each other, first you read about what you catch?

$\boldsymbol{S}$ : yes it means that each person gives 3 likes for his friend with himself.

P: example?

S: for example, for example, Nana loves her own picture and then snaps a picture of it with you.

$\boldsymbol{P}:$ So there are three?

$\boldsymbol{S}$ : yes one person likes 3 .

...

$\boldsymbol{P}:$ then after you understand what you are doing?

$\boldsymbol{S}$ : For the first one it's about Facebook's likes. That's 3 times straight 3. Because one person has 3 likes so it's straightforward 3 times 3. (CF1)

$\boldsymbol{P}$ : what do you draw on your results, what do you mean by that?

$\boldsymbol{S}$ : just prove it to be easier

P: what do you do (b) how do you do it?

$\boldsymbol{S}$ : it's just the same as there are 4 children 4 times 4.

$\boldsymbol{P}$ : what if (c)?

$\boldsymbol{S}$ : If it's 3 children 3 times 3,4 children 4 times 4 . So if the child is $n$ times $n$. (CF1)

From the results of students written response and interviews conducted by Participant 2, it can be seen that Participant 2 performs a repeat check or ensures that the formulated formula is correct. Participant 2 re-checks by making a diagram as well as the results of the process. the work process carried out by Participant 2 can be seen from the following diagram (Figure 5). 


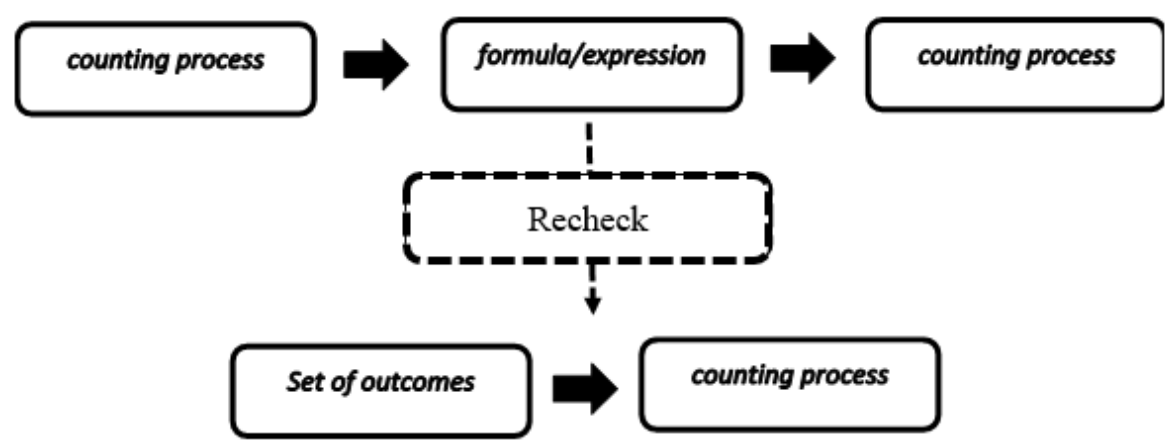

Figure 5. Combinatorial thinking process Participant 2 on problem 1

In working on Participant 2, found Participant 2 checks again in a different way to ensure that the formula is arranged correctly. Participant 2 raises number 3 which represents 3 likes that each person has then multiplied by 3 which represents 3 children who give likes. Participant 2 marks each child as 1 number as well as every liking given by each child. At this stage Participant 2 interpret the context of the child and likes each into a certain number which means the Participant enters the stage of the counting process. Participants assume that if each child likes 3 times and many children have 3 then the number of likes is recorded as $3 \times 3$. Likewise in points (b) there are $4 \times 4$ likes. This can also be shown how this formula is raised by the Participant for any number requested, that is $\mathrm{n} \times \mathrm{n}$ like. Point (c) turns off that the Participant is able to build a formula from the existing context. This means that here from the counting process, the Participant goes to the formula / expression stage. From these stages it is shown that from the meaning of a problem, certain numbers are arranged and the Participant tries to build the appropriate formula. So from the counting process the Participant goes to formula / expression. Then on the work sheet the Participant writes the results in the form of numbers and not formulas as in the results of the interview. So here the Participant performs the calculation process (counting process) based on the formula that was built.

After the Participant completes in this way the Participant states to do proof by using an image or diagram on the worksheet. This shows that the formula built by the Participant still needs to know the truth. The Participant makes a branch diagram where the branch shows each child. Furthermore, of course this diagram is used to list all the possibilities so that it can be seen that the mathematical formulas that he uses are correct. At this stage the Participant goes to stage set of outcomes. Then to find the results the Participant counts each branch on the diagram made. This is stated in the following interview passage.

$P:$ then number two what did you do the first time, did you do the problem twice why?

$S$ : First of all, like the number one, it turns out the number two if done by the way the number one result will be double. And later working on it is more difficult.

P: what's the difference?

$S:$ if number one can love himself, while the number two may not be the color it meets the color itself because of the two-color composition. So it must be different (CS2)

From the interview it can be seen that the Participant marks each branch in the diagram as 1 number which means then by calculating all as 1 number obtained by intact number is 9. So the probability calculation process that appears shows that the Participant counts based on the list and the Participant enters the stage counting process. The Participant lists the list as a number and then gets the number of likes that are recorded as many as the list of possibilities that exist. 


\subsection{Problems 2}

The results of Participant 1 on problem 1 are given by Figure 6 .

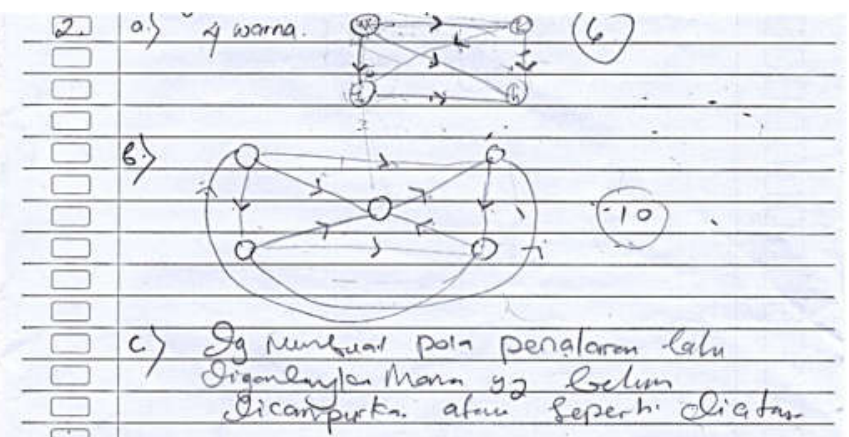

Figure 6. Students written response on Participant 1 on problem 2

Based on these results, interviews were conducted with Participant 1 to find out the results of the work on the answer sheet.

P: how about number 2?

$S:$ There are 4 colors in composition 2. Then I make a bunder-bunder pattern. Then then match 2 colors. (CS1)

P: What is the meaning of bunder-bunder?

S: it's red, yellow, green, and blue. Then mixed.

P: Can you get 6?

S: from these arrows. Calculated number. (CS2)

P: How come the arrows are just red to blue and blue to red doesn't exist?

$\boldsymbol{S}$ : It's blue to red, it's the same as red to blue.

$P:$ oh yeah, then?

$\boldsymbol{S}$ : then I combine it.

Q: How come the yellow to red doesn't have arrows?

$S:$ it's red to yellow it's the same.

P: keep that (c)?

$S:$ by making a pattern of reasoning then combined.

Q: What about ten?

S: stay as low as ten continue to be combined. But that's a complicated way.

From the results of the students written response and interviews, it can be shown that Participant 1 makes it salty to obtain many possibilities. Participant 1 then counts many arrows in the diagram as a solution to the problem given. The combinatorial thinking process of Participant 1 on the second problem can be described as follows.

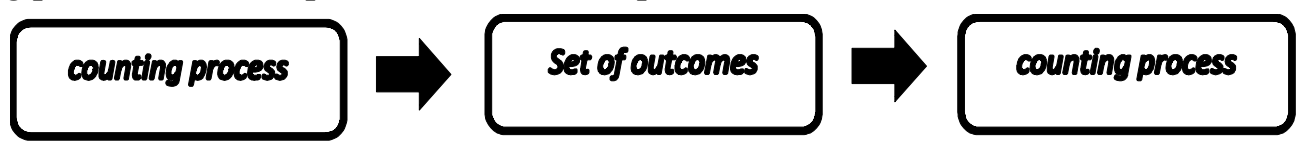

Figure 7. Combinatorial thinking process Participant 1 on problem 2

In problem 2, Participant 1 first raises numbers that are 4 and 2. The Participant means 4 as the number of colors to use. This consistency applies to students written response points (b). The Participant does the same thing except that the number that appears opens 4 but 5 . By showing the number 4 or 5 to represent the many colors that will be used, the Participant is in the stage of the counting process. From the meaning of the problem, then the Participant makes a diagram with the number of dots as much as 4 as a form of representation of numbers that appear before. Nodes made given a symbol. The 
Participant gives a symbol for each different color. then the Participant connects each dot as a pointer that the pointing arrow is one possibility that appears. In this section the Participant makes a list of possibilities indirectly with the help of a diagram. So the next stage is set of outcomes. The Participant forms a diagram with the help of the initial meaning of the number of flags to be used. In addition, the Participant represents each connecting arrow as one possibility. The Participant resolves this problem by counting each arrow. In this case the Participant did a counting process based on the set of outcomes previously done. The Participant views one arrow as one possibility which will be represented as 1 number. The results of this counting process are 6 . In addition, the Participant is sure to never pass formula / expression. From the interview, it can be seen that the Participant failed to make a general formula.

Meanwhile, the results of work on Participant 2 are also obtained as shown in Figure 8 and Figure 9.

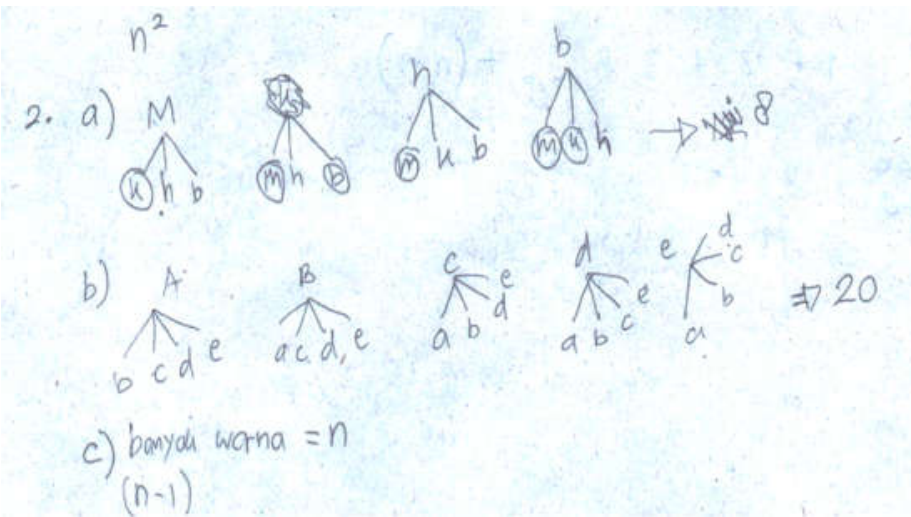

Figure 8. Participant 2's work on problem 2 first

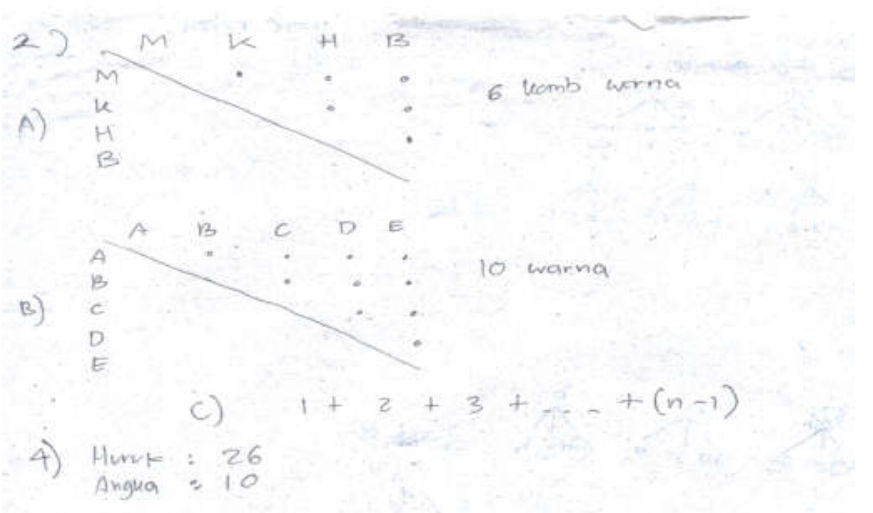

Figure 9. the results of the Participant 2 work on the second problem 2

Based on the results of the work carried out interviews with the Participant 2. The results of the interview are as follows.

$\boldsymbol{P}:$ then number two what did you do the first time, did you do the problem twice why?

$S$ : First of all, like the number one, it turns out the number two if done by the way the number one result will be double. (CF1) (CF2) And later working on it is more difficult.

$\cdots$

$\boldsymbol{P}:$ then after understanding the meaning of the problem, what do you do?

$S$ : First of all, it will be like number one after making a diagram like number one, there is a double, red one, found yellow, then there is yellow, found red again. (CS2) 
$\boldsymbol{P}$ : what do you mean by mastering?

$\boldsymbol{S}$ : if the first method is red and yellow, you can find yellow red. Yellow red is recorded once.

$\boldsymbol{P}$ : Then this one is not given a point.

$\boldsymbol{S}$ : the problem will be recorded twice

$\boldsymbol{P}$ : what do you do after that?

$\boldsymbol{S}:$ yes, the total points are in total, there are 6 color combinations. (CS2)

$\boldsymbol{P}$ : Did you use multiplication like number one?

S: $n o$

From the results of the Participant's work and the interviews conducted, the Participant did the work twice. The first execution of the Participant does the same multiplication as the work on the first problem. Participant 2 multiplies 4 by 4 . Then the Participant performs a check using the list he made and is different from the problem 1. Participant 2 only makes 3 branches with 4 main branches and the results 12 . Through this step, there are irregularities between the results by multiplying and listing made then one Participant to work again and re-understand the purpose of the problem 2. Then Participant 2 composes a table that meets the conditions on the problem 2 . Then from the table calculated the number of possibilities and the result is 6 combinations. In general, the process of Participant 2 on problem 2 is presented in Figure 10.

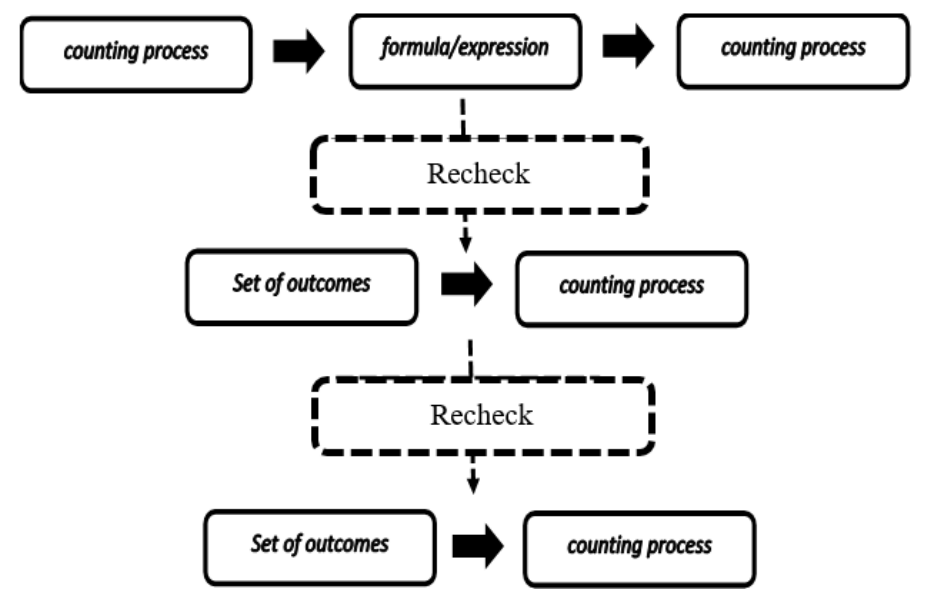

Figure 10. Combinatorial thinking process Participant 2 on problem 2

Participant 1 at the beginning of working on problem 2 is the same as problem 1 . That is, initially students interpret many flags, namely 4 as a number which is then multiplied by itself. Participant 2 uses the general formula obtained from the previous stage. So that from the number that appears, the Participant composes it in the multiplication rules that have been previously obtained. This means that the Participant composes a formula / expression based on the counting process that was done before. Then the Participant resolved the problem with the counting process. Where from the formula obtained by Participant 2 calculate the results of multiplication and get the result is 16 . However, after the Participant checked again using the diagram drawn the Participant found that the result was 12. The diagram drawn by the Participant reflects each color which is then paired with other colors but not with herself. So the branches in each color only exist 3 . So that when the Participant counts it turns out the results are 12. This shows that from the results of the Participant there is a difference from the first work and re-examination. Then the Participant found irregularities in the list. So the list or diagram that is made is not in 
accordance with the context of the problem given. So here the Participant conducts a reexamination by using the list or entering the stage of set of outcome. Then from the list, Participant 2 counts each branch and the results are different from the formula / expression Participant 2 did before. So that the Participant works again the problem 2. The Participant then lists the tables with columns and rows in the form of color names. Then the Participant gives a point to each cell that has never been filled by another color combination so that the tick-point is like in Figure 8. The points are a possible set that shows that the Participant is at the stage of set of outcomes. After that from the points then the Participant looks for what color combinations can be arranged. By memaiai that each point is a number of Participants knowing that by calculating all the points the Participant will be able to solve the problem 2. So that from set of outcomes the Participant performs the calculation process or counting process by calculating the points that exist.

This study showed that students can do the task about combinatorics although they did not ever learn formally abaout combinatorics. The students' test result show that Lockwood combinatorial thinking model [2] fit to students' combinatorial thinking in solving mathematics problem. Lockwood, Swinyard, and Caughman [11] show that by listing possible outcomes students can reinvent formulae of combinatorics. It shows that it is not impossible to take correlation between set of outcomes and formula/expression. The other study show that students build formula from previous formula [12]. According to previous study, this study also show that by using list of outcomes that students got from diagram, students recheck the answer to make sure the formula that they use. So, this study also support to Lockwood combinatorial thinking model in different way from previous study.

Generally, male and female have different ways of thinking in solving mathematical problems. They have different also in explaining strategy that be used [13]. This study specified that combinatorial thinking model male and female student have different ways. Male students recheck his answer but female student did not.

\section{Conclusion}

In problem 1 each Participant tends to solve problems directly multiplying. They immediately use the multiplication rule. Even though, Participant 2 checks again by making a diagram as an amplifier that works correctly. Each Participant was then given an interview about the process. Interviews conducted also strengthen if the Participant directly uses multiplication rules from the context of the problem given.

The general way of thinking both participant from the previous result was strengthened by the result of second problem. Both Participants tended to solve it through stages set of outcomes. Participants make diagrams or tables with the aim of helping to sort every possibility that appears. Then from the table the Participant calculates the number of possibilities that appear and are considered as the result or resolution of the problem given. Then the Participant also conducted an interview where the results of the interview further strengthened that both Participants made tables or diagrams based on their understanding of the context given. Participant 2 did the test by recheck the answer again but the participant 1 did not.

In general, Participant 1 performs the work to do the work without doing the inspection again. Participant 1 tends to believe in the way it is done. Participant 2 on each question performed always checks. In problem 1, both Participants succeeded in generating formulas and basically they could make formulation. But the formula was made by Participant 1 are in the form of sentences and Participant 2 checks again by making a table. At first Participant 2 did it directly using the formula used in the first problem. After checking again Participant 2 knows that the answer is wrong. Finally 
Participant 2 makes the table as a tool register possibilities. Participant 1 managed to answer correctly with the help of a chart made to list all possibilities. Both Participants basically bring up the answer correctly by using the help of a table or diagram to bring up a list of possibilities.

\section{Sugestion}

That is, the Participant through stages of set of outcomes to successfully answer correctly. Lockwood and Gibson[14] states that by making a list of possibilities, students will know better what they are counting. The results of this study support that indeed through the stages of set of outcomes the Participant managed to answer correctly and be confident in the answer. Even though there are those who directly use the formula to complete and even then only in simple cases such as multiplication rules. In the first session both Participants can solve it by using a formula / expression and then entering the counting process. Even though Participant 2 checks the process using another method. Aini, Juniati, and Siswono [15] it was also shown that the strategies used by students in solving the problem of applying permutations checked again to convince themselves. Participants also answered correctly in various ways they did. According to Lockwood and Gibson[14], set of outcomes can be the accurate strategy to solve combinatorical problems. By improving listing skill, it can take students to understand high order thinking problems. Set of outcomes also one of strategy that appear in both Participants it means it is simple to do without more information about the methods. induction procement in learning can be done by using this approach.

\section{References}

[1] Lockwood, E., \& Reed, Z. (2018). Leveraging Specific Context and Outcomes to Generalize in Combinatorial Setting. INDRUM 2018, INDRUM Network, University of Agder, Kristiansand, Norway.

[2] Lockwood, E. (2013). A model of students' combinatorial thinking. Journal of Mathematical Behavior, 32, 251-265.

[3] Lockwood, E. \& Reed. Z. (2018). Reinforcing Mathematical Concepts and Developing Mathematical Practices Through Combinatorial Activity. Teaching and Learning Discrete Mathematics Worldwide: Curriculum and Research, 93-101.

[4] Ammamiarihta, Syahputra, E., \& Surya, E. (2017). Development of Learning Devices Oriented Problem Based Learning to Increase Student's Combinatorial Thinking in Mathematical Problem Solving Ability. Advances in Social Science, Education and Humanities Research, 104, 334-339

[5] Rezaie, M., \& Gooya, Z. (2011). What do I mean by combinatorial thinking? Procedia Social and Behavioral Sciences, 11, 122-126.

[6] Budayasa, I. K. (2008). Matematika Diskrit. Surabaya: Unesa University Prss.

[7] Rosen, K. H. (2011). Elementay Number Theory and Its Applications (6th ed.). Boston: Pearson.

[8] English, L. D. (2005). Combinatorics and the development of children's combinatorial reasoning. Exploring probability in school: Challenges for teaching and learning, 40, 121-141.

[9] Melusova, J., \& Vidermanova, K. (2015). Upper-secondary Students' Strategies for Solving Combinatorial Problems. Procedia - Social and Behavioral Sciences, 197, 1703-1709.

[10] Lockwood, E. (2011). Student connections among counting problems: An exploration using actor-oriented transfer. Educational Studies in Mathematics, 78(3), 307-322. doi:10.1007/s10649-011-9320-7 
[11] Lockwood, E., Swinyard, Craig A., Caughman, John S. (2015). Patterns, Sets of Outcomes, and Combinatorial Justification: Two Students' Reinvention of Counting Formulas. International Journal of Research in Undergraduate Mathematics Education, 1(1), 27 - 62.

[12] Lockwood, E., Reed, Z., \& Caughman, J. S. (2017). An Analysis of Statements of the Multiplication Principle in Combinatorics, Discrete, and Finite Mathematics Textbooks. International Journal of Research in Undergraduate Mathematics Education, 3(3), 381-416.

[13] Syukriani, A., Juniati, D., \& Siswono, T. Y. (2017). Investigating Adaptive Reasoning and Strategic Competence: Difference Male and Female. AIP Conference Proceedings. Retrieved from https://doi.org/10.1063/1.4994436

[14] Lockwood, E., \& Gibson, B. R. (2015). Combinatorial tasks and outcome listing: Examining productive listing among undergraduate students. Educ Stud Math, 91, 247-270. doi:10.1007/s10649-015-9664-5

[15] Aini, N., Juniati, D., \& Siswono, T. Y. E. (2018) Understanding The Combinatorial Thinking Through The Strategy Used by Students Cognitive Reflective in Solving Permutation. International Conference on Mathematics and Science Education, 3, 652-657. 